\title{
Updated mortality among diverse operating segments of a petroleum company
}

\author{
R Jeffrey Lewis, A Robert Schnatter, Arnold M Katz, F S Thompson, Neil Murray, \\ Gail Jorgensen, Gilles Thériault
}

\begin{abstract}
Objectives-To update mortality for 34560 employees from diverse operating segments of a Canadian petroleum company; and to investigate potential relations with occupational factors.
\end{abstract}

Methods-Employees from 1964-83 were linked to the Canadian mortality data base to provide 11 years additional follow up. There were 6760 deaths and 750683 person-years of follow up compared with 3909 and 428190 , respectively, in the earlier study. Analyses used standardised mortality ratios (SMRs) to compare worker cause specific mortality with the Canadian general population. Duration of employment and latency analyses were performed for causes previously found to be increased in this and other petroleum cohorts, as well as any findings of interest. Results-For the period 1964-94, employees experienced significantly low overall mortality (SMR =0.86 men, SMR =0.80 women). Kidney cancer, which has been increased in some studies of petroleum workers, was not increased. Acute nonlymphocytic leukaemia in exposed operating segments was consistent with the expected or only slightly, non-significantly increased. The most notable finding was increased deaths from mesothelioma among refinery and petrochemical workers (SMR 8.68; 95\% confidence interval (95\% CI) 5.51 to 13.03$)$, most of whom were long term employees in jobs with presumed exposure to asbestos (mechanical and pipefitters). Deaths from multiple myeloma among marketing and distribution workers, which were previously increased, remained increased (SMR 2.08; $95 \%$ CI 0.95 to 3.95 ) in the update period 1984-94; however, there was no clear pattern by duration of employment or latency. Aortic aneurysms, which also were previously significantly increased among marketing and distribution workers approached the expected in the update period (SMR 1.18; 95\% CI 0.65-1.98). Analyses by duration of employment showed suggestive trends for aortic aneurysms, but earlier studies of this cohort have not found a relation between aortic aneurysms and exposure to hydrocarbons.

Conclusion-The additional 2851 deaths and 322493 person-years of follow up strengthened the assessment of mortality patterns relative to occupational factors.
With the exception of mesothelioma, no clear work related increases in disease were identified.

(Occup Environ Med 2000;57:595-604)

Keywords: epidemiology; occupational exposures; petroleum

In 1992, Schnatter et $a l^{1}$ reported the mortality experience of 34597 employees from diverse operating segments of a large petroleum company. This study represented one of the few petroleum industry cohorts to examine mortality in operating segments other than refining - such as marketing and distribution, pipeline, and production workers. The differences in exposure across operating segments ${ }^{2}$ provides the opportunity to compare findings to identify potential health hazards.

Mortality follow up to the end of 1983 indicated that workers had an overall healthy profile. Deaths due to leukaemia, lymphomas, and kidney cancer, which have been increased in other populations of refinery workers, ${ }^{3-6}$ were less than or similar to the general population. Mesothelioma was increased in refinery workers, and suggestive increases in malignant melanoma and multiple myeloma were found among upstream (jobs involved in getting oil out of the ground) and marketing or distribution workers, respectively. These two findings were related to duration of employment, but not to ranked estimates of frequency of exposure to hydrocarbons. ${ }^{17}$ A previous study found excess deaths from colon cancer, ${ }^{8}$ but this finding was not confirmed in the last update by Schnatter et al. ${ }^{1}$

Eleven years of additional mortality follow up are now available for the cohort. These data provide substantially increased power to determine if increases in disease found previously have continued over time. Accordingly, the objectives of the present study were: (a) to assess mortality patterns with an additional 11 years of follow up, $(b)$ to investigate potential relations with occupational factors for causes previously found to be increased in this cohort (multiple myeloma, malignant melanoma, mesothelioma, and colon cancer, already discussed $)^{18}$ and other petrochemical industry cohorts (lymphohaematopoietic cancer, brain and kidney cancer, mesothelioma, and angiosarcoma), ${ }^{3-6-11}$ and (c) to evaluate mortality patterns for different operating segments of the company.

\section{Methods}

Identification and definition of the study cohort is described elsewhere. ${ }^{1}$ Briefly, the 
cohort includes all employees who worked for 1 year or more during the period 1 January 1964 and 31 December 1983, as well as retired workers alive on 1 January 1964. Consistency checks and editing identified 32 duplicate records and five workers who did not meet the cohort entry criteria, thereby reducing the final cohort to 34560 employees.

The work history and operating segment designations from the previous study were used in this investigation. Details on the summarisation of work histories and assessment of the operating segments are provided by Schnatter et al. ${ }^{1}$ The 11 operating segments examined were: (1) refinery, (2) agricultural chemicals, (3) petrochemical, (4) marketing and distribution, (5) marine, (6) exploration, drilling, and production, (7) pipeline, (8) coal and minerals, (9) office, (10) fabricated building products subsidiary, and (11) other and unknown.

Updated mortality information was obtained from three sources: $(a)$ the Canadian mortality data base maintained by Statistics Canada, $(b)$ internal company death notifications, and (c) the United States National Death Index. Firstly, all 34560 employees were submitted to Statistics Canada for updating vital status with the generalised record linkage system of Statistics Canada, which linked cohort records to the Canadian mortality data base for the years 1964-94. This process identified 6550 deaths. The National Death Index identified an additional 82 deaths. Finally, company death notices and death information from the previous study identified another 128 , out of a total of 6760 deaths.

Underlying cause of death was coded by Statistics Canada with the seventh or eighth revised international classification of diseases (ICD-7 or ICD-8) coding for deaths identified through the Canadian mortality data base linkage. Underlying cause of death was determined by a certified nosologist for all remaining deaths. Due to the lack of specificity in disease for ICD-7 for lymphohaematopoietic cancer and tumours of the brain and central nervous system (CNS) (two diseases of initial interest), ICD-7 death certificates for these causes were recoded to the ICD-8. Baseline mortalities for these causes were also appropriately adjusted (see later). A total of $75(1.1 \%)$ decedents did not have information on underlying cause of death; these subjects were included as deaths for total mortality but were not assigned to a cause specific category. Finally, due to potential exposure to asbestos and vinyl chloride monomer at certain locations, a certified nosologist reviewed all death certificates for selected ICD codes (see appendix of Schnatter

Table 1 Vital, demographic, and employment characteristics* of all operating segments of a petroleum company combined, by sex

\begin{tabular}{|c|c|c|c|}
\hline Characteristic & Men & Women & Total \\
\hline Alive & 20068 & 7732 & 27800 \\
\hline Dead (n (\%) of total) & $6254 \quad(24)$ & $506(6)$ & 6760 \\
\hline Year of entry into follow up (mean) & 1970 & 1972 & 1970 \\
\hline Duration of employment (mean, y) & 19.2 & 9.9 & 17.0 \\
\hline Person-years & 571656 & 179027 & 750683 \\
\hline
\end{tabular}

$\star$ Data as of 1994 or exit from follow up. et $a l^{1}$ ) for any mention of mesothelioma or angiosarcoma.

The analysis entered employees into follow up as of 1 January 1964, or, if employed after 1 January 1963, 1 year after their date of first employment. Person-years at risk were accumulated by 5 year categories of age, sex, and period until date of death or the end of study (31 December 1994), whichever was earliest. Persons of unknown vital status were assumed to be alive until the study end date, owing to the relative completeness of the Canadian mortality data base ${ }^{12}$ and the National Death Index. ${ }^{13}$ Expected deaths were computed through a modified life table approach with the occupational cohort mortality analysis program (OCMAP), version $2.0,{ }^{14}$ which multiplied person-years by mortalities for the general Canadian population.

Mortalities for the general Canadian population were obtained from Statistics Canada. Because the company has operations and employees in all 10 provinces and some territories (and employees often move between locations), national population rates were most appropriate. Rates from ICD-8 for lymphohaematopoietic cancer and tumours of the brain and CNS were extrapolated back to the ICD-7 period because of recoding procedures for these deaths (already discussed). Due to the lack of mortalities for mesothelioma in the general Canadian population, we used mesothelioma incidences to calculate expected deaths. These incidences were assembled with data from Statistics Canada's population based tumour registry in a manner that mirrored the identification of mesothelioma deaths in the cohort. Specifically, the numerator included any tumour registry case with an ICD code equal to one of the ICD codes for which we reviewed death certificates by hand and where the morphology code indicated mesothelioma. Mesothelioma is a highly fatal disease; thus the bias with incidences, rather than mortalities is expected to be small.

For the analysis, we examined mortality separately for each operating segment due to differences in exposure across segments. For example, refinery workers are potentially exposed to a range of hydrocarbons - such as crude oil, intermediate streams associated with processes such as alkylation or reforming, and finished products. Conversely, marketing workers are usually not exposed to crude oil, but may be exposed to finished petroleum products - for example, gasoline, diesel, heating fuel-on an intermittent basis, usually by inhalation. Marine workers also have potential inhalation exposure to finished products, most often during loading and unloading operations. Pipeline, drilling, and production workers may experience dermal exposure to crude oil and drilling muds. A more detailed description of potential exposures in the petroleum industry can be found in Runion et al. ${ }^{2}$

We calculated standardised mortality ratios (SMRs) for the total cohort and by operating segment for diseases of initial interest and several other causes. Analyses by duration of employment $(0-4,5-14,15-24,25-34$, and 
Table 2 Mortality resultst for all operating segments of a petroleum company combined, by sex, 1964-94

\begin{tabular}{|c|c|c|}
\hline Cause of death (ICD-8 codes) & Men: observed/expected SMR $(95 \%$ CI) & Women: observedlexpected SMR $(95 \%$ CI) \\
\hline All causes of death (000-999) & $6254 / 7284.07$ & $506 / 630.61$ \\
\hline \multirow{2}{*}{ Endocrine, nutritional, and metabolic diseases (240-279) } & $0.86(0.84 \text { to } 0.88)^{\star}$ & $0.80(0.73 \text { to } 0.88)^{\star}$ \\
\hline & $118 / 153.06$ & $9 / 19.02$ \\
\hline \multirow[t]{2}{*}{ Circulatory diseases (390-458) } & $3084 / 3403.74$ & $\begin{array}{l}0.47(0.22 \text { to } 0.90)^{n} \\
182 / 234.51\end{array}$ \\
\hline & $0.91(0.87 \text { to } 0.94)^{\star}$ & $0.78(0.67 \text { to } 0.90)^{\star}$ \\
\hline Respiratory diseases $(460-519)$ & $455 / 578.97$ & $23 / 35.32$ \\
\hline & $0.79(0.72 \text { to } 0.86)^{\star}$ & $0.65(0.41 \text { to } 0.98)^{\star}$ \\
\hline Digestive diseases $(520-577)$ & $219 / 288.59$ & $24 / 26.32$ \\
\hline & $0.76(0.66 \text { to } 0.87)^{\star}$ & $0.91(0.58$ to 1.36$)$ \\
\hline Accidents, poisonings, and violence (e800-e999) & $375 / 576.30$ & $28 / 55.07$ \\
\hline & $0.65(0.59 \text { to } 0.72)^{\star}$ & $0.51(0.34 \text { to } 0.74)^{\star}$ \\
\hline Malignant neoplasms (140-209) & $1611 / 1804.57$ & $198 / 205.59$ \\
\hline & $0.89(0.85 \text { to } 0.94)^{\star}$ & $0.96(0.83$ to 1.11$)$ \\
\hline Oesophagus (150) & $42 / 43.93$ & $3 / 1.95$ \\
\hline & $0.96(0.69$ to 1.29$)$ & - \\
\hline Stomach (151) & $83 / 118.83$ & $4 / 7.45$ \\
\hline & $0.70(0.56 \text { to } 0.87)^{\star}$ & $0.54(0.15$ to 1.38$)$ \\
\hline Large intestine, except rectum (153) & $183 / 172.70$ & $19 / 21.68$ \\
\hline & $1.06(0.91$ to 1.22$)$ & $0.88(0.53$ to 1.37$)$ \\
\hline Rectum and rectosigmoid junction (154) & $55 / 63.38$ & $3 / 5.03$ \\
\hline & $0.87(0.65$ to 1.13$)$ & $0.60(0.12$ to 1.74$)$ \\
\hline Liver (155.0) & $12 / 15.78$ & $2 / 1.01$ \\
\hline & $0.76(0.39$ to 1.33$)$ & - \\
\hline Pancreas (157) & $82 / 95.61$ & $6 / 9.22$ \\
\hline & $0.86(0.68$ to 1.06$)$ & $0.65(0.24$ to 1.42$)$ \\
\hline Bronchus and lung (162.1) & $478 / 564.35$ & $34 / 30.98$ \\
\hline & $0.85(0.77 \text { to } 0.93)^{\star}$ & $1.10(0.76$ to 1.53$)$ \\
\hline Malignant melanoma (172) & $22 / 16.62$ & $1 / 2.58$ \\
\hline & $1.32(0.83$ to 2.00$)$ & - \\
\hline Breast (174) & $1 / 2.21$ & $51 / 48.79$ \\
\hline & - & $1.04(0.78$ to 1.37$)$ \\
\hline Uterine cancer $(180,182.0)$ & $0 / 0.00$ & $10 / 9.85$ \\
\hline & - & $1.02(0.49$ to 1.87$)$ \\
\hline Ovary, fallopian tube, and broad ligaments (183) & $0 / 0.00$ & $20 / 12.64$ \\
\hline & - & $1.58(0.97$ to 2.44$)$ \\
\hline Prostate (185) & $176 / 178.10$ & $0 / 0.00$ \\
\hline & $0.99(0.85$ to 1.14$)$ & - \\
\hline Kidney (189.0-189.2) & $41 / 42.91$ & $3 / 3.28$ \\
\hline & $0.96(0.69$ to 1.30$)$ & - \\
\hline Bladder (188) & $46 / 56.34$ & $3 / 2.16$ \\
\hline & $0.82(0.60$ to 1.09$)$ & - \\
\hline Brain (malignant) (191) & $44 / 43.32$ & $5 / 5.95$ \\
\hline & $1.02(0.74$ to 1.36$)$ & $0.84(0.27$ to 1.96$)$ \\
\hline Brain neoplasms (all) $(191,225.0,238.1)$ & $46 / 49.30$ & $5 / 6.79$ \\
\hline & $0.93(0.68$ to 1.24$)$ & $0.74(0.24$ to 1.72$)$ \\
\hline All nervous system neoplasms (malignant, benign, and unspecified) $(191,192$, & $52 / 53.91$ & $6 / 7.61$ \\
\hline 225,238$)$ & $0.96(0.72$ to 1.26$)$ & $0.79(0.29$ to 1.72$)$ \\
\hline Reticulum cell sarcoma (200.0) & $8 / 6.53$ & $1 / 0.67$ \\
\hline & $1.22(0.53$ to 2.41$)$ & - \\
\hline Lymphosarcoma (200.1) & $9 / 9.55$ & $1 / 0.89$ \\
\hline & $0.94(0.43$ to 1.79$)$ & - \\
\hline Hodgkin's disease (201) & $7 / 10.25$ & $1 / 1.26$ \\
\hline & $0.68(0.28$ to 1.41$)$ & - \\
\hline Non-Hodgkin's lymphoma $(200,202.0,202.2)$ & $49 / 50.06$ & $5 / 6.10$ \\
\hline & $0.98(0.72$ to 1.29$)$ & $0.82(0.27$ to 1.91$)$ \\
\hline Multiple myeloma (203) & $30 / 27.14$ & $2 / 2.80$ \\
\hline & $1.10(0.75$ to 1.58$)$ & - \\
\hline Leukaemias (204-207) & $56 / 62.85$ & $6 / 6.97$ \\
\hline & $0.89(0.67$ to 1.16$)$ & $0.86(0.32$ to 1.88$)$ \\
\hline Acute non-lymphocytic leukaemia $(205.0,206.0,207.2)$ & $23 / 15.00$ & $0 / 2.20$ \\
\hline & $1.53(0.97$ to 2.30$)$ & - \\
\hline Acute lymphoid leukaemia (204.0) & $1 / 3.16$ & $0 / 0.50$ \\
\hline & - & - \\
\hline Chronic lymphoid leukaemia (204.1) & $9 / 13.49$ & $1 / 0.80$ \\
\hline & $0.67(0.30$ to 1.27$)$ & - \\
\hline Acute myeloid (myelomonocytic) leukaemia (205.0) & $19 / 13.76$ & $0 / 2.05$ \\
\hline & $1.38(0.83$ to 2.16$)$ & - \\
\hline Chronic myeloid leukaemia (205.1) & $6 / 7.00$ & $1 / 0.96$ \\
\hline & $0.86(0.32$ to 1.87$)$ & - \\
\hline Other leukaemias $(204.9,205.9,206.1,206.9,207.0,207.1,207.9)$ & $17 / 24.13$ & $4 / 2.49$ \\
\hline & $0.70(0.41$ to 1.13$)$ & - \\
\hline Benign neoplasms (210-228) & $7 / 5.16$ & $1 / 0.99$ \\
\hline & $1.36(0.54$ to 2.79$)$ & - \\
\hline Amyotrophic lateral sclerosis (348.0) & $18 / 11.11$ & $1 / 1.40$ \\
\hline & $1.62(0.96$ to 2.56$)$ & - \\
\hline Cerebrovasular disease $(430-438)$ & $457 / 524.16$ & $49 / 54.21$ \\
\hline & $0.87(0.79 \text { to } 0.96)^{\star}$ & $0.90(0.67$ to 1.20$)$ \\
\hline Acute myocardial infarction (410) & $1014 / 1231.35$ & $37 / 68.01$ \\
\hline & $0.82(0.77 \text { to } 0.88)^{\star}$ & $0.54(0.38 \text { to } 0.75)^{\star}$ \\
\hline Diseases of arteries, arterioles, and capillaries (440-448) & $239 / 209.91$ & $17 / 13.85$ \\
\hline & $1.14(1.00$ to 1.29$)$ & $1.23(0.72$ to 1.96$)$ \\
\hline Aortic aneurysm (441) & $109 / 85.73$ & $7 / 3.50$ \\
\hline & $1.27(1.04 \text { to } 1.53)^{\star}$ & $2.00(0.80$ to 4.12$)$ \\
\hline Chronic obstructive pulmonary disease (519.3) & $113 / 152.28$ & $6 / 7.03$ \\
\hline & $0.74(0.61 \text { to } 0.89)^{\star}$ & $0.85(0.31$ to 1.86$)$ \\
\hline Cirrhosis (571) & $87 / 126.41$ & $12 / 9.88$ \\
\hline & $0.69(0.55 \text { to } 0.85)^{\star}$ & $1.22(0.63$ to 2.12$)$ \\
\hline Suicide (e950-e959) & $97 / 149.03$ & $12 / 15.11$ \\
\hline & $0.65(0.53 \text { to } 0.79)^{\star}$ & $0.79(0.41$ to 1.39$)$ \\
\hline
\end{tabular}

$\star 95 \%$ CI does not include 1.00

†Expected deaths based on Canadian general population mortalities. 
$\geqslant 35$ years) and latency ( $<20$ years, $\geqslant 20$ years) were performed for causes of initial interest and any findings of interest. We used an alternative latency grouping ( $<10$ years, $\geqslant 10$ years) to assess the impact of our choice of cut off point for this measure, and there were no appreciable differences for any of the findings. Accordingly, only results based on the $<20$ and $\geqslant 20$ years category are presented. Finally, to determine whether increases found in the previous study persisted over time, analyses for mesothelioma, malignant melanoma, multiple myeloma, and aortic aneurysms were performed separately for the previous (1964-83) and update (1984-94) study periods. Ninety five per cent confidence intervals (95\% CIs) were calculated for SMRs with the exact method $^{15}$ under the assumption that the observed numbers of deaths followed a Poisson distribution. The SMRs and 95\% CIs are not presented when both the observed and expected number of deaths are less than five to reduce presentation of less meaningful results (none of the excluded SMRs were significantly increased).

\section{Results}

TOTAL COHORT

Table 1 presents the vital status, demographic, and employment characteristics of the total cohort. The cohort comprised primarily men $(n=26322)$ with an average 19.2 years of employment. Twenty four per cent of the men are dead. There is a reasonably large group of women $(n=8238)$, but a small proportion $(6 \%)$ of them are dead.

Mortality due to all causes was significantly reduced in both men (SMR 0.86; 95\% CI 0.84 to 0.88 ) and women (SMR 0.80; $95 \%$ CI 0.73 to 0.88 , table 2). The SMRs for many causes of initial interest such as kidney, colon, and cancer of the brain or CNS and the lymphomas were near unity or only slightly, non-significantly increased. The only significant increase found was for aortic aneurysms in men (SMR 1.27; 95\% CI 1.04 to 1.53 ), which resulted in a borderline significant increase in the broader category of diseases of the arteries, arterioles, and capillaries. Increases in disease that approached significance included acute nonlymphocytic leukaemia (SMR 1.53; 95\% CI 0.97 to 2.30 ) and amyotrophic lateral sclerosis (SMR 1.62; 95\% CI 0.96 to 2.56) in men, and ovarian related malignancies in women (SMR $1.58 ; 95 \%$ CI 0.97 to 2.44 ). Finally, there was

Table 3 Mortality resultst for mesothelioma among male employees of a petroleum company ever employed in refinery or petrochemical operations by period (1964-94)

\begin{tabular}{|c|c|c|}
\hline \multirow[b]{2}{*}{ Period } & \multicolumn{2}{|l|}{ Operating segment } \\
\hline & $\begin{array}{l}\text { All segments combined } \\
\text { Observedlexpected } \\
\text { SMR }(95 \% \text { CI })\end{array}$ & $\begin{array}{l}\text { Refinery or petrochemical } \\
\text { Observed/expected } \\
\text { SMR }(95 \% \text { CI) }\end{array}$ \\
\hline \multirow[t]{2}{*}{$1964-83$} & $7 / 1.90$ & $6 / 0.80$ \\
\hline & $3.68(1.48 \text { to } 7.59)^{\star}$ & $7.50(2.75 \text { to } 16.32)^{\star}$ \\
\hline \multirow[t]{2}{*}{$1984-94$} & $17 / 4.94$ & $17 / 1.86$ \\
\hline & $3.44(2.00 \text { to } 5.51)^{\star}$ & $9.14(5.32 \text { to } 14.63)^{\star}$ \\
\hline \multirow[t]{2}{*}{ Total period (1964-94) } & $24 / 6.83$ & $23 / 2.65$ \\
\hline & $3.51(2.25 \text { to } 5.22)^{\star}$ & $8.68(5.51 \text { to } 13.03)^{\star}$ \\
\hline
\end{tabular}

$\star 95 \%$ CI does not include 1.00 .

†Expected deaths based on Canadian general population incidences. one death due to angiosarcoma identified among male workers (no female deaths for this cause were identified). Information on job history for this man indicated a date of first employment in the 1940s but no history of employment at the company's plant where vinyl chloride was used to manufacture polyvinyl chloride.

Due to the relatively few deaths among women, the remaining analyses presented are for men, except where noted.

\section{MESOTHELIOMA}

There were 24 deaths due to mesothelioma identified among men (no deaths from mesothelioma were identified among women). The resulting SMR for the total cohort was significantly increased (SMR 3.51; 95\% CI 2.25 to 5.22, table 3).

Examination of the 24 cases of mesothelioma showed an average year of first employment of 1942 (range 1927-78), a mean duration of employment of 34 (range 12-44) years, and a preponderance of mechanical and pipefitter jobs (occupations with potential exposure to asbestos). Because the refinery and petrochemical operating segments were potentially exposed to asbestos and include mechanical or pipefitter occupations, we calculated an SMR for the combined refinery and petrochemical segment; the resulting SMR was increased about ninefold and was significant (SMR 8.68; 95\% CI 5.51 to $13.03,23$ observed, table 3 ). It is noteworthy that 23 of the 24 total mesothelioma cases identified were employed in either refining or petrochemicals. The single case without any refinery or petrochemical experience was classified as exploration, drilling, or production; he was employed in the 1930s and had very incomplete work history information, although the job information available mentioned mechanical foreman. Finally, analyses of mesothelioma mortality over time for the refinery and petrochemical segment indicated that rates had increased slightly in the update period (SMR 9.14; $95 \%$ CI 5.32 to 14.63 , observed 17 , 1984-94) compared with the original study period (SMR 7.50; 95\% CI 2.75 to 16.32, observed six, 1964-83, table 3).

GENERAL MORTALITY BY OPERATING SEGMENT The following operating segments are not discussed due to few deaths: agricultural chemicals $(n=31)$, building products $(n=9)$, and coal and minerals $(n=7)$. There were 151 deaths in petrochemicals, and 42 deaths among employees with unknown operating segment, but no significant excesses were found for any diseases in these two groups (with the exception of the deaths from mesothelioma in refinery and petrochemical workers already discussed).

\section{Refinery}

Deficits for all causes (SMR 0.92; 95\% CI 0.89 to 0.96 ) and all cancers (SMR 0.94; 95\% CI 0.87 to 1.01 ) were found in refinery workers (table 4). The SMRs for diseases of initial interest-such as cancer of the colon and 
Table 4 Mortality resultst for male employees of a petroleum company, by operating segment (1964-94)

\begin{tabular}{|c|c|c|c|c|c|}
\hline \multirow[b]{2}{*}{ Cause of death (ICD-8 codes) } & \multicolumn{5}{|l|}{ Operating segment } \\
\hline & $\begin{array}{l}\text { Refinery }(n=9266) \\
\text { Observedlexpected } \\
\text { SMR }(95 \% \text { CI })\end{array}$ & $\begin{array}{l}\text { Marketing or distribution } \\
(n=6800) \\
\text { Observedlexpected } \\
\text { SMR }(95 \% \text { CI })\end{array}$ & $\begin{array}{l}\text { Marine }(n=1656) \\
\text { Observed/expected } \\
\text { SMR }(95 \% \text { CI })\end{array}$ & $\begin{array}{l}\text { Exploration, drilling, } \\
\text { production or pipeline } \\
\text { ( } n=4432) \\
\text { Observedlexpected } \\
\text { SMR }(95 \% \text { CI) }\end{array}$ & $\begin{array}{l}\text { Office }(n=7111) \\
\text { Observed/expected } \\
\text { SMR }(95 \% \text { CI })\end{array}$ \\
\hline \multirow{2}{*}{ All causes of death (000-999) } & $2905 / 3157.10$ & $1917 / 2203.06$ & $350 / 436.81$ & $560 / 762.59$ & $860 / 1358.38$ \\
\hline & $0.92(0.89 \text { to } 0.96)^{\star}$ & $0.87(0.83 \text { to } 0.91)^{\star}$ & $0.80(0.72 \text { to } 0.89)^{\star}$ & $0.73(0.68 \text { to } 0.80)^{\star}$ & $0.63(0.59 \text { to } 0.68)^{\star}$ \\
\hline & $62 / 65.97$ & $32 / 46.29$ & $7 / 9.24$ & $7 / 16.07$ & $20 / 28.80$ \\
\hline$(240-279)$ & $0.94(0.72$ to 1.20$)$ & $0.69(0.47 \text { to } 0.98)^{\star}$ & $0.76(0.30$ to 1.56$)$ & $0.44(0.18 \text { to } 0.90)^{\star}$ & $0.69(0.42$ to 1.07$)$ \\
\hline Circulatory diseases (390-458) & $1485 / 1533.13$ & $964 / 1035.82$ & $161 / 191.24$ & $233 / 313.67$ & $378 / 574.27$ \\
\hline & $0.97(0.92$ to 1.02$)$ & $0.93(0.87 \text { to } 0.99)^{\star}$ & $0.84(0.72 \text { to } 0.98)^{\star}$ & $0.74(0.65 \text { to } 0.84)^{\star}$ & $0.66(0.59 \text { to } 0.73)^{\star}$ \\
\hline Respiratory diseases $(460-519)$ & $232 / 264.45$ & $118 / 174.65$ & $27 / 30.49$ & $33 / 49.26$ & $60 / 93.06$ \\
\hline & $0.88(0.77$ to 1.00$)$ & $0.68(0.56 \text { to } 0.81)^{\star}$ & $0.88(0.58$ to 1.29$)$ & $0.67(0.46 \text { to } 0.94)^{\star}$ & $0.64(0.49 \text { to } 0.83)^{\star}$ \\
\hline Digestive diseases $(520-577)$ & $96 / 120.42$ & $68 / 88.83$ & $9 / 19.12$ & $24 / 33.74$ & $30 / 58.57$ \\
\hline & $0.80(0.65 \text { to } 0.97)^{\star}$ & 0.77 (0.59 to 0.97$)$ & $0.47(0.22 \text { to } 0.89)^{\star}$ & $0.71(0.46$ to 1.06$)$ & $0.51(0.35 \text { to } 0.73)^{\star}$ \\
\hline Accidents, poisonings, and violence (e800-e999) & $139 / 210.75$ & $103 / 165.33$ & $21 / 38.78$ & $64 / 90.45$ & $61 / 148.99$ \\
\hline & $0.66(0.55 \text { to } 0.78)^{\star}$ & $0.62(0.51 \text { to } 0.76)^{\star}$ & $0.54(0.34 \text { to } 0.83)^{\star}$ & $0.71(0.54 \text { to } 0.90)^{\star}$ & $0.41(0.31 \text { to } 0.53)^{\star}$ \\
\hline Malignant neoplasms (140-209) & $714 / 759.78$ & $505 / 549.87$ & $101 / 119.69$ & $170 / 206.32$ & $254 / 360.44$ \\
\hline & $0.94(0.87$ to 1.01$)$ & $0.92(0.84$ to 1.00$)$ & $0.84(0.69$ to 1.02$)$ & $0.82(0.70 \text { to } 0.96)^{\star}$ & $0.70(0.62 \text { to } 0.80)^{\star}$ \\
\hline Oesophagus (150) & $20 / 18.17$ & $14 / 13.51$ & $1 / 3.08$ & $3 / 5.30$ & $1 / 9.15$ \\
\hline & $1.10(0.67$ to 1.70$)$ & $1.04(0.57$ to 1.74$)$ & - & $0.57(0.12$ to 1.66$)$ & $0.11(0.01 \text { to } 0.61)^{\star}$ \\
\hline Stomach (151) & $42 / 52.73$ & $31 / 36.14$ & $6 / 7.02$ & $8 / 11.63$ & $7 / 20.82$ \\
\hline & $0.80(0.57$ to 1.08$)$ & $0.86(0.58$ to 1.22$)$ & $0.86(0.31$ to 1.86$)$ & $0.69(0.30$ to 1.36$)$ & $0.34(0.14 \text { to } 0.69)^{\star}$ \\
\hline Large intestine, except rectum (153) & $65 / 73.73$ & $63 / 52.62$ & $22 / 11.08$ & $17 / 18.88$ & $34 / 33.38$ \\
\hline & $0.88(0.68$ to 1.12$)$ & $1.20(0.92$ to 1.53$)$ & $1.98(1.24 \text { to } 3.00)^{\star}$ & $0.90(0.52$ to 1.44$)$ & $1.02(0.70$ to 1.42$)$ \\
\hline Rectum and rectosigmoid junction (154) & $30 / 27.58$ & $12 / 19.35$ & $3 / 3.93$ & $2 / 6.60$ & $11 / 11.71$ \\
\hline & $1.09(0.73$ to 1.55$)$ & $0.62(0.32$ to 1.08$)$ & - & $0.30(0.04$ to 1.09$)$ & $0.94(0.47$ to 1.68$)$ \\
\hline Liver (155.0) & $7 / 6.40$ & $1 / 4.81$ & $2 / 1.13$ & $1 / 2.01$ & $1 / 3.42$ \\
\hline & $1.09(0.44$ to 2.25$)$ & - & - & - & - \\
\hline Pancreas (157) & $33 / 40.52$ & $28 / 29.15$ & $4 / 6.31$ & $10 / 10.74$ & $16 / 18.78$ \\
\hline & $0.81(0.56$ to 1.14$)$ & $0.96(0.64$ to 1.39$)$ & $0.63(0.17$ to 1.62$)$ & $0.93(0.45$ to 1.71$)$ & $0.85(0.49$ to 1.38$)$ \\
\hline Bronchus and lung (162.1) & $221 / 231.21$ & $150 / 172.64$ & $36 / 40.61$ & $42 / 69.87$ & $67 / 119.82$ \\
\hline & $0.96(0.83$ to 1.09$)$ & $0.87(0.74$ to 1.02$)$ & $0.89(0.62$ to 1.23$)$ & $0.60(0.43 \text { to } 0.81)^{\star}$ & $0.56(0.43 \text { to } 0.71)^{\star}$ \\
\hline Malignant melanoma (172) & $4 / 6.17$ & $8 / 5.02$ & $1 / 1.23$ & $7 / 2.48$ & $7 / 4.19$ \\
\hline & $0.65(0.18$ to 1.66$)$ & $1.59(0.69$ to 3.14$)$ & - & $2.82(1.13 \text { to } 5.81)^{\star}$ & $1.67(0.67$ to 3.45$)$ \\
\hline Prostate (185) & $83 / 81.56$ & $50 / 53.64$ & $4 / 9.49$ & $21 / 15.06$ & $27 / 28.58$ \\
\hline & $1.02(0.81$ to 1.26$)$ & $0.93(0.69$ to 1.23$)$ & $0.42(0.12$ to 1.08$)$ & $1.40(0.86$ to 2.13$)$ & $0.94(0.62$ to 1.37$)$ \\
\hline Kidney (189.0-189.2) & $16 / 17.61$ & $15 / 13.15$ & $3 / 2.98$ & $5 / 5.23$ & $3 / 9.01$ \\
\hline & $0.91(0.52$ to 1.48$)$ & $1.14(0.64$ to 1.88$)$ & - & $0.96(0.31$ to 2.23$)$ & $0.33(0.07 \text { to } 0.97)^{\star}$ \\
\hline Bladder (188) & $25 / 25.46$ & $12 / 17.04$ & $2 / 3.16$ & $6 / 5.09$ & $4 / 9.39$ \\
\hline & $0.98(0.64$ to 1.45$)$ & $0.70(0.36$ to 1.23$)$ & - & $1.18(0.43$ to 2.57$)$ & $0.43(0.12$ to 1.09$)$ \\
\hline Brain (malignant) (191) & $19 / 16.32$ & $9 / 13.20$ & $4 / 3.31$ & $11 / 6.40$ & $14 / 10.66$ \\
\hline & $1.16(0.70$ to 1.82$)$ & $0.68(0.31$ to 1.29$)$ & - & $1.72(0.86$ to 3.08$)$ & $1.31(0.72$ to 2.20$)$ \\
\hline Brain neoplasms (all) $(191,225.0,238.1)$ & $18 / 18.72$ & $10 / 15.00$ & $4 / 3.72$ & $12 / 7.17$ & $16 / 11.98$ \\
\hline & $0.96(0.57$ to 1.52$)$ & $0.67(0.32$ to 1.23$)$ & - & $1.68(0.86$ to 2.92$)$ & $1.34(0.76$ to 2.17$)$ \\
\hline All nervous system neoplasms (malignant, benign & $21 / 20.52$ & $10 / 16.41$ & $6 / 4.05$ & $14 / 7.79$ & $17 / 13.03$ \\
\hline and unspecified) $(191,192,225,238)$ & $1.02(0.63$ to 1.56$)$ & $0.61(0.29$ to 1.12$)$ & $1.48(0.54$ to 3.22$)$ & $1.80(0.98$ to 3.02$)$ & $1.30(0.76$ to 2.09$)$ \\
\hline Reticulum cell sarcoma (200.0) & $6 / 2.79$ & $1 / 2.00$ & $0 / 0.41$ & $0 / 0.72$ & $1 / 1.25$ \\
\hline & 2.15 (0.79 to 4.69$)$ & - & - & - & - \\
\hline Lymphosarcoma (200.1) & $1 / 4.18$ & $3 / 2.91$ & $2 / 0.58$ & $0 / 0.99$ & $4 / 1.73$ \\
\hline & - & - & - & - & - \\
\hline Hodgkin's disease (201) & $1 / 3.96$ & $3 / 3.10$ & $0 / 0.70$ & $2 / 1.44$ & $2 / 2.42$ \\
\hline & - & - & - & - & - \\
\hline Non-Hodgkin's lymphoma $(200,202.0,202.2)$ & $22 / 20.20$ & $17 / 15.20$ & $3 / 3.46$ & $3 / 6.33$ & $9 / 10.89$ \\
\hline & $1.09(0.68$ to 1.65$)$ & $1.12(0.65$ to 1.79$)$ & - & $0.47(0.10$ to 1.38$)$ & $0.83(0.38$ to 1.57$)$ \\
\hline Multiple myeloma (203) & $8 / 11.48$ & $16 / 8.26$ & $2 / 1.79$ & $2 / 3.05$ & $5 / 5.35$ \\
\hline & $0.70(0.30$ to 1.37$)$ & $1.94(1.11 \text { to } 3.15)^{\star}$ & - & - & $0.93(0.30$ to 2.18$)$ \\
\hline Leukaemias (204-207) & $19 / 26.30$ & $21 / 18.98$ & $2 / 4.00$ & $5 / 7.23$ & $11 / 12.68$ \\
\hline & $0.72(0.44$ to 1.13$)$ & $1.11(0.68$ to 1.69$)$ & - & $0.69(0.22$ to 1.61$)$ & $0.87(0.43$ to 1.55$)$ \\
\hline Acute non-lymphocytic leukaemia (205.0, & $6 / 6.05$ & $6 / 4.54$ & $1 / 1.02$ & $3 / 1.90$ & $6 / 3.27$ \\
\hline $206.0,207.2)$ & $0.99(0.36$ to 2.16$)$ & $1.32(0.49$ to 2.88$)$ & - & - & $1.84(0.67$ to 4.00$)$ \\
\hline Acute lymphoid leukaemia (204.0) & $0 / 1.24$ & $0 / 0.91$ & $0 / 0.20$ & $0 / 0.43$ & $1 / 0.73$ \\
\hline & - & - & - & - & \\
\hline Chronic lymphoid leukaemia (204.1) & $5 / 5.92$ & $4 / 4.10$ & $0 / 0.82$ & $0 / 1.35$ & $2 / 2.44$ \\
\hline & $0.85(0.27$ to 1.97$)$ & - & - & - & - \\
\hline Acute myeloid (melomonocytic) leukaemia & $4 / 5.51$ & $5 / 4.16$ & $0 / 0.95$ & $3 / 1.78$ & $6 / 3.05$ \\
\hline$(205.0)$ & $0.73(0.20$ to 1.86$)$ & $1.20(0.39$ to 2.80$)$ & - & - & $1.97(0.72$ to 4.29$)$ \\
\hline Chronic myeloid leukaemia (205.1) & $3 / 2.78$ & $1 / 2.10$ & $0 / 0.47$ & $1 / 0.91$ & $1 / 1.57$ \\
\hline & - & - & - & - & - \\
\hline Other leukaemias $(204.9,205.9,206.1,206.9$, & $5 / 10.32$ & $10 / 7.31$ & $1 / 1.48$ & $1 / 2.61$ & $1 / 4.63$ \\
\hline $207.0,207.1,207.9)$ & $0.48(0.16$ to 1.13$)$ & 1.37 (0.66 to 2.52$)$ & - & - & - \\
\hline Benign neoplasms (210-228) & $5 / 2.18$ & $1 / 1.57$ & $1 / 0.33$ & $0 / 0.59$ & $0 / 1.02$ \\
\hline & $2.29(0.74$ to 5.35$)$ & - & - & - & - \\
\hline Amyotrophic lateral sclerosis (348.0) & $7 / 4.35$ & $6 / 3.39$ & $1 / 0.83$ & $1 / 1.51$ & $5 / 2.56$ \\
\hline & $1.61(0.65$ to 3.31$)$ & $1.77(0.65$ to 3.85$)$ & - & - & $1.95(0.63$ to 4.56$)$ \\
\hline Cerebrovascular disease (430-438) & $228 / 246.23$ & $138 / 159.28$ & $15 / 25.50$ & $24 / 40.32$ & $57 / 77.87$ \\
\hline & $0.93(0.81$ to 1.05$)$ & $0.87(0.73$ to 1.02$)$ & $0.59(0.33 \text { to } 0.97)^{\star}$ & $0.60(0.38 \text { to } 0.89)^{\star}$ & $0.73(0.55 \text { to } 0.95)^{\star}$ \\
\hline Acute myocardial infarction (410) & $445 / 527.48$ & $326 / 374.06$ & $77 / 78.97$ & $90 / 133.28$ & $129 / 234.51$ \\
\hline & $0.84(0.77 \text { to } 0.93)^{\star}$ & $0.87(0.78 \text { to } 0.97)^{\star}$ & $0.98(0.77$ to 1.22$)$ & $0.68(0.54 \text { to } 0.83)^{\star}$ & $0.55(0.46 \text { to } 0.65)^{\star}$ \\
\hline Diseases of arteries, arterioles, and capillaries & $129 / 98.51$ & $69 / 63.73$ & $10 / 10.39$ & $18 / 16.27$ & $20 / 31.54$ \\
\hline$(440-448)$ & $1.31(1.09 \text { to } 1.56)^{\star}$ & $1.08(0.84$ to 1.37$)$ & $0.96(0.46$ to 1.77$)$ & $1.11(0.66$ to 1.75$)$ & $0.63(0.39 \text { to } 0.98)^{\star}$ \\
\hline Aortic aneurysm (441) & $46 / 37.99$ & $40 / 25.70$ & $7 / 5.08$ & $11 / 8.31$ & $13 / 15.07$ \\
\hline & $1.21(0.89$ to 1.62$)$ & $1.56(1.11 \text { to } 2.12)^{\star}$ & $1.38(0.55$ to 2.84$)$ & $1.32(0.66$ to 2.37$)$ & $0.86(0.46$ to 1.48$)$ \\
\hline Chronic obstructive pulmonary disease (519.3) & $53 / 65.95$ & $29 / 45.44$ & $7 / 9.22$ & $14 / 15.27$ & $19 / 28.04$ \\
\hline & $0.80(0.60$ to 1.05$)$ & $0.64(0.43 \text { to } 0.92)^{\star}$ & $0.76(0.30$ to 1.56$)$ & $0.92(0.50$ to 1.54$)$ & $0.68(0.41$ to 1.06$)$ \\
\hline Cirrhosis (571) & $43 / 48.50$ & $25 / 39.54$ & $3 / 9.88$ & $9 / 18.11$ & $9 / 30.14$ \\
\hline & $0.89(0.64$ to 1.19$)$ & $0.63(0.41 \text { to } 0.93)^{\star}$ & $0.30(0.06 \text { to } 0.89)^{\star}$ & $0.50(0.23 \text { to } 0.94)^{\star}$ & $0.30(0.14 \text { to } 0.57)^{\star}$ \\
\hline Suicide (e950-e959) & $31 / 51.80$ & $25 / 41.41$ & $3 / 10.33$ & $19 / 25.48$ & $23 / 41.29$ \\
\hline & $0.60(0.41 \text { to } 0.85)^{\star}$ & $0.60(0.39 \text { to } 0.89)^{\star}$ & $0.29(0.06 \text { to } 0.85)^{\star}$ & $0.75(0.45$ to 1.16$)$ & $0.56(0.35 \text { to } 0.84)^{\star}$ \\
\hline
\end{tabular}

$\star 95 \%$ CI does not include 1.00

†Expected deaths based on Canadian general population mortalities. 
Table 5 Mortality resultst for selected causes of death by duration of employment and operating segment among men with 20 or more years latency from a petrochemical company, 1964-94

\begin{tabular}{|c|c|c|c|c|c|c|}
\hline \multirow[b]{2}{*}{ Cause of death (ICD-8 codes) } & \multirow[b]{2}{*}{ Operating segment } & \multicolumn{5}{|c|}{ Duration of employment $(y)$} \\
\hline & & $\begin{array}{l}0-4 \\
\text { Observed/expected } \\
\text { SMR }(95 \% \mathrm{CI})\end{array}$ & $\begin{array}{l}5-14 \\
\text { Observed/expected } \\
\text { SMR }(95 \% \mathrm{CI})\end{array}$ & $\begin{array}{l}15-24 \\
\text { Observed/expected } \\
\text { SMR }(95 \% \text { CI })\end{array}$ & $\begin{array}{l}25-34 \\
\text { Observed/expected } \\
\text { SMR }(95 \% \mathrm{CI})\end{array}$ & $\begin{array}{l}\geqslant 35 \\
\text { Observed/expected } \\
\text { SMR }(95 \% C I)\end{array}$ \\
\hline Malignant melanoma (172) & $\begin{array}{l}\text { Marketing or } \\
\text { distribution }\end{array}$ & $0 / 0.26$ & $1 / 0.37$ & $3 / 0.87$ & $2 / 1.57$ & $0 / 0.88$ \\
\hline Multiple myeloma (203) & $\begin{array}{l}\text { Marketing or } \\
\text { distribution }\end{array}$ & $\begin{array}{l}1 / 0.22 \\
-\end{array}$ & $\begin{array}{l}1 / 0.37 \\
-\end{array}$ & $\begin{array}{l}2 / 1.54 \\
-\end{array}$ & $\begin{array}{l}10 / 3.27 \\
3.06(1.47 \text { to } \\
5.63)^{\star}\end{array}$ & $\begin{array}{l}2 / 2.44 \\
-\end{array}$ \\
\hline Aortic aneurysm (411) & $\begin{array}{l}\text { Marketing or } \\
\text { distribution }\end{array}$ & $\begin{array}{l}0 / 0.37 \\
-\end{array}$ & $\begin{array}{l}0 / 0.69 \\
-\end{array}$ & $\begin{array}{l}6 / 4.77 \\
1.26(0.46 \text { to } 2.74)\end{array}$ & $\begin{array}{l}11 / 10.37 \\
1.06(0.53 \text { to } 1.90)\end{array}$ & $\begin{array}{l}20 / 8.69 \\
2.30(1.40 \text { to } \\
3.55)^{\star}\end{array}$ \\
\hline $\begin{array}{l}\text { Large intestine, except rectum } \\
\text { (153) }\end{array}$ & Marine & $\begin{array}{l}2 / 0.51 \\
-\end{array}$ & $\begin{array}{l}1 / 0.62 \\
-\end{array}$ & $\begin{array}{l}5 / 1.85 \\
2.70(0.88 \text { to } 6.30)\end{array}$ & $\begin{array}{l}3 / 3.93 \\
-\end{array}$ & $\begin{array}{l}8 / 2.91 \\
2.75(1.19 \text { to } \\
5.41)^{\star}\end{array}$ \\
\hline Brain (malignant) (191) & $\begin{array}{l}\text { Exploration, drilling, } \\
\text { production, pipeline }\end{array}$ & $\begin{array}{l}0 / 0.24 \\
-\end{array}$ & $\begin{array}{l}1 / 0.49 \\
-\end{array}$ & $\begin{array}{l}3 / 1.31 \\
-\end{array}$ & $\begin{array}{l}2 / 2.01 \\
-\end{array}$ & $2 / 0.55$ \\
\hline
\end{tabular}

$\star 95 \%$ CI does not include 1.0 .

†Expected deaths based on Canadian general population mortalities.

Table 6 Mortality from malignant melanoma, multiple myeloma, and aortic aneurysm by period for male marketing or distribution workers from a petrochemical company (1964-94)

\begin{tabular}{|c|c|c|}
\hline \multirow[b]{2}{*}{ Cause of death (ICD-8 code) } & \multicolumn{2}{|l|}{ Period } \\
\hline & $\begin{array}{l}\text { Previous study period } \\
\text { (1964-83) } \\
\text { Observedlexpected } \\
\text { SMR }(95 \% \text { CI) }\end{array}$ & $\begin{array}{l}\text { Update study period } \\
\text { (1984-94) } \\
\text { Observedlexpected } \\
\text { SMR (95\% CI) }\end{array}$ \\
\hline Malignant melanoma (172) & $\begin{array}{l}6 / 2.33 \\
2.58(0.95 \text { to } 5.60)\end{array}$ & $2 / 2.70$ \\
\hline Multiple myeloma (203) & $\begin{array}{l}7 / 3.94 \\
1.78(0.71 \text { to } 3.66)\end{array}$ & $\begin{array}{l}9 / 4.33 \\
2.08(0.95 \text { to } 3.95)\end{array}$ \\
\hline Aortic aneurysm (411) & $\begin{array}{l}26 / 13.85 \\
1.88(1.23 \text { to } 2.75)^{\star}\end{array}$ & $\begin{array}{l}14 / 11.85 \\
1.18(0.65 \text { to } 1.98)\end{array}$ \\
\hline
\end{tabular}

$\star 95 \%$ CI does not include 1.0 .

†Expected deaths based on Canadian general population mortalities.

kidney-were less than 1.00, whereas deaths due to tumours of the brain and CNS and causes related to leukaemia were at or near expected and not significant. The large, imprecise increases in reticulosarcoma and benign neoplasms are findings from the previous study, as no new deaths were found in the update period for these diseases. Finally, deaths due to amyotrophic lateral sclerosis were non-significantly increased (SMR 1.61;95\% CI 0.65 to 3.31 ), and there was a significant increase in diseases of the arteries, arterioles, and capillaries (SMR 1.31; 95\% CI 1.09 to 1.56).

\section{Marketing or distribution}

Employees in marketing and distribution also experienced deficits of deaths due to all causes (SMR 0.87; 95\% CI 0.83 to 0.91 ) and all cancers (SMR 0.92; 95\% CI 0.84 to 1.00 , table 4 ). Deaths from cancer of the lung and brain and CNS were less than expected, whereas deaths due to kidney cancer, colon cancer, and leukaemia were only slightly, non-significantly increased. As in the previous study, deaths due to aortic aneurysms were significantly increased (SMR 1.56; 95\% CI 1.11 to 2.12). Also, there was a non-significant increase in amyotrophic lateral sclerosis (SMR 1.77; 95\% CI 0.65 to 3.85 ).

We performed analyses by latency and duration of employment for malignant melanoma, multiple myeloma, and aortic aneurysms (table 5). Results for less than 20 years latency are not shown by duration of employment due to small numbers (observed 2, expected 1.06 for malignant melanoma; observed 0 , expected 0.42 for multiple myeloma; and observed 3, expected 0.80 for aortic aneurysms). Deaths were concentrated among long duration employees, especially for aortic aneurysms. The time course of these diseases showed only two new deaths from malignant melanoma in the update period (expected 2.70), whereas mortality due to multiple myeloma continued to be increased (table 6). Mortality from aortic aneurysms decreased from a significant excess in the previous study period (SMR $1.88 ; 95 \%$ CI 1.23 to 2.75 ) to only a slight non-significant increase in the update period (SMR 1.18; 95\% CI 0.65 to 1.98 ).

\section{Marine}

Most causes of death in marine workers were less than expected, including all causes and all cancers; however, colon cancer was significantly increased (SMR 1.98; 95\% CI 1.24 to 3.00 , table 4 ). The increase in deaths due to all nervous system neoplasms was due to increased deaths observed in the previous study (only one new death occurred in the update period versus 1.98 expected). There was also a non-significant increase in aortic aneurysms (SMR 1.38 ; 95\% CI 0.55 to 2.84 ).

Table 5 presents SMRs for colon cancer by duration of employment. Results for less than 20 years latency are not shown due to small numbers (observed 3, expected 1.25). There was no steady increasing trend in SMRs with duration of employment, but the SMR for $\geqslant 20$ years latency and $\geqslant 35$ years employment was significant (SMR 2.75; 95\% CI 1.19 to 5.41).

Exploration, drilling, production, and pipeline All causes and all cancers were significantly reduced, and mortality for the causes of initial interest, cancer of the kidney and colon and the leukaemias and lymphomas, were less than or consistent with expected (table 4). There was a significant increase in malignant melanoma (SMR 2.82; 95\% CI 1.13 to 5.81 , obs 7 ), but this was largely a finding from the previous study (observed 1, expected 1.50 for the period 1984-94). As such, no new analyses by 
duration and latency were performed for this disease.

The increase in deaths due to all neoplasms of the nervous system approached significance and was due primarily to a non-significant excess of malignant brain tumours (SMR 1.72; $95 \%$ CI 0.86 to 3.08 , table 4 ). However, among workers with $\geqslant 20$ years latency there was no pattern in SMRs by duration of employment, although this analysis was based on small numbers (table 5) (results for less than 20 years latency were too small for meaningful analysis: observed 3, expected 1.8). Finally, there was a slight, non-significant excess of aortic aneurysms (SMR 1.32; 95\% CI 0.66 to 2.37 ).

Office

Male office workers had a favourable overall health profile, with most causes of death being less than expected. The few increases in disease found were all non-significant, and each had been found in other operating segments. The most notable findings were the non-significant excess of acute non-lymphocytic leukaemia (SMR 1.84; 95\% CI 0.67 to 4.00 ) (and acute myelogenous leukaemia) and the deficit of aortic aneurysms (SMR 0.86; 95\% CI 0.46 to 1.48 , table 4$)$.

Among women who worked in offices (the only segment with sufficient numbers), the noteworthy findings were non-significant increases in deaths due to cancers related to the ovaries (SMR 1.76; 95\% CI 0.96 to 2.94, observed 14) and aortic aneurysms (SMR $2.71 ; 95 \%$ CI 0.88 to 6.33 , observed five, data not shown). Analyses for the total cohort indicated that the increase in cancer related to the ovaries was concentrated among women with at least 20 years latency; but SMRs were highest among the group with shortest duration of employment (SMR for the 0-4 years employment group: SMR 3.68; 95\% CI 1.20 to 8.59 , observed five).

\section{Discussion}

This study updated mortality for a large cohort of workers from diverse operating segments of a Canadian petroleum company. The major strengths of the study include its large size, the ability to compare mortality across different operating segments, the relatively long average duration of employment (19.2 years) and latency (21.7 years) among male employees, and the likely completeness of mortality follow up. Given these strengths, most excesses of chronic diseases related to occupational exposures should have been detected, if present.

Like any epidemiological investigation, our study has some limitations. Firstly, we did not have data on exposures of specific employees. We stratified on operating segment to compare mortality across broadly defined exposure groups, although some of the individual results were based on small numbers, which limited statistical power to detect increases. Secondly, some employees had incomplete operating segment work information, which necessitated extrapolation of information on work history of the last or first known operating segment for these workers. This may have resulted in misclassification of operating segment, which if non-differential in nature may have obscured associations that were present. Finally, we did not have data on potential confounding factors-such as smoking and socioeconomic status.

OVERALL MORTALITY

The results suggest that employees continued to experience a mortality profile that was favourable overall. Deficits of deaths were found for most causes of death, a pattern consistent with studies of other petroleum workers. ${ }^{46}$ This reduced mortality is likely to be the result of the healthy worker effect, a phenomenon attributable to the selection of healthy people into the workforce and the socioeconomic benefits of continuing employment-for example, greater access to medical care, etc. ${ }^{16}{ }^{17}$

CAUSES OF INITIAL INTEREST

The most noteworthy finding was the large, significant increase in deaths from mesothelioma among refinery and petrochemical workers. This finding was previously reported in this cohort, ${ }^{1}$ and is consistent with other studies of refinery and petrochemical workers reporting increased deaths from mesothelioma. ${ }^{9} 10$ 18-20 Virtually all of the mesotheliomas occurred in long term employees with long latency who worked in jobs with potential exposure to asbestos (primarily mechanical and pipefitter jobs). Analyses by period showed that mortality had increased in the update period, a finding which suggests that the burden of past asbestos exposure in this cohort is continuing. ${ }^{21} 22$ Finally, despite increased deaths from mesothelioma among refinery and petrochemical workers, lung cancer was not increased. Other refinery and petrochemical cohorts have similar findings for lung cancer and mesothelioma. ${ }^{6} 91018-20$

It is possible that our manual review of death certificates for mesothelioma resulted in an upward bias of the SMR; however, this bias should be accounted for given that we generated comparison rates in a manner that mirrored our manual review procedures. Also, the use of incidences to calculate expected deaths from mesothelioma may have resulted in a slight downward bias, thereby inflating the SMR. In summary, the observed excess most likely documents the result of past asbestos exposures in this cohort.

We did not find deaths to be increased for kidney cancer, a cause of initial interest. Although there is some epidemiological ${ }^{52324}$ and toxicological ${ }^{25}$ evidence to suggest an increased risk associated with exposures related to petroleum, several detailed studies have found no relation between kidney cancer and exposures to hydrocarbons in refinery, ${ }^{26} 27$ marketing, ${ }^{28}$ and petrochemical workers. ${ }^{29}$

The increased deaths due to acute nonlymphocytic leukaemia is of interest given the potential for exposure to benzene in this cohort and the well established link between benzene and acute non-lymphocytic leukaemia. ${ }^{30} 31$ 
However, as a whole, there is no persuasive evidence to suggest that this excess was related to benzene or any other workplace exposure. Notably, the increase was focused in unexposed office workers, who are not exposed to benzene. There was a trend towards higher SMRs in workers with longer durations of employment and longer latencies, but this has little meaning in an office environment. More importantly, a previous nested case-control study found little evidence for an association between leukaemia and exposure to benzene or general hydrocarbons in the marketing and distribution segment of this cohort. ${ }^{72}$ It is possible that some non-occupational factor played a part in the excess of acute nonlymphocytic leukaemia-such as smokingwhich is related to myelogenous leukaemia ${ }^{33}$ and acute non-lymphocytic leukaemia in particular. ${ }^{34}$ However, there would have to be a substantial difference in smoking patterns between employees and the general population to produce even a modest increase in the SMR (unlikely given the deficit of lung cancer). Thus, the finding could be due to chance or other uncontrolled confounding factors.

Another form of lymphopoietic cancer that was increased was multiple myeloma, which was concentrated among marketing and distribution workers. The 1.8-fold increase reported previously is still evident in this update. Some investigators have suggested that multiple myeloma may be related to exposure to low concentrations of benzene. ${ }^{3135}$ Interestingly, whereas the previous study found trends by duration of employment and latency that were suggestive of a possible occupational relation, additional mortality follow up seems to have attenuated these trends. An earlier study of marketing and distribution workers in this cohort found some evidence of a possible association between multiple myeloma and exposure to hydrocarbons. ${ }^{7}$ On the other hand, a previous case-control study of multiple myeloma and exposures to low concentrations of benzene nested within the marketing and distribution segment of this cohort, ${ }^{32}$ found no relation with multiple myeloma; but this was based on only seven cases. In other studies of distribution workers, multiple myeloma was not increased among distribution workers in the United Kingdom. ${ }^{36}$ Further, a study of over 18000 distribution workers in the United States found no relation between quantitative estimates of exposure to gasoline and mortality from multiple myeloma. ${ }^{28}$ Finally, a metaanalysis of studies of distribution workers, which included over 48000 employees, showed mortality from multiple myeloma to be slightly less than expected (SMR 0.93; 95\% CI 0.69 to 1.23$).^{37}$ Thus, there is little persuasive evidence to suggest that the modest increase found is related to benzene or other workplace exposures, although this possibility cannot be completely ruled out.

Our results indicated that colon cancer was significantly increased in marine workers. Analyses by duration of employment and latency in the marine segment showed a significant excess in the group with $\geqslant 20$ years latency and $\geqslant 35$ years employment, although no pattern of increasing SMRs with increasing years worked was evident. Interestingly, the closely related cause of rectal cancer was not increased in any operating segment, including marine workers; however, the number of deaths from rectal cancer in the marine segment was small.

An earlier study of marketing and distribution workers in this cohort found colon cancer to be increased, but the evidence for an association between exposure to hydrocarbons and this malignancy was inconsistent. ${ }^{7}$ Also, a previous study of refinery workers (some of whom were in this cohort) found a twofold increase in colon cancer, ${ }^{8}$ but this is no longer evident in this update. A study of distribution workers in the United Kingdom found colon cancer as expected, with the exception of a significant increase among clerical and administrative workers (SMR 1.62; 95\% CI 1.12 to 2.26 ). Most studies of refinery workers have not reported increased mortality due to colon cancer. ${ }^{4}{ }^{6}$ Thus, given the scientific literature, the lack of an excess of rectal cancer, and the lack of a biologically plausible hypothesis to explain how inhalation exposures to finished petroleum products might selectively target the colon, there is no compelling reason to suspect an occupational association for this disease. Further, the modest risk found means that non-occupational factors - such as diet, lack of physical activity, etc- which were not controlled for, cannot be ruled out.

Malignant melanoma, which was increased among upstream and marketing and distribution workers in the previous study, returned to levels consistent with the general population in the update period. Although numbers were small, an excess as high as sixfold, as previously reported, was not consistent with data from this update. The apparent reduction in deaths probably reflects improved survival rates for melanoma achieved in recent years. ${ }^{38}{ }^{39}$ However, there has also been a dramatic increase in incidence of melanoma in the general population, possibly due to exposure to ultraviolet light and other factors. ${ }^{38}$ Finally, it is noteworthy that a study of distribution workers in the United Kingdom $^{36}$ did not find increased deaths due to melanoma. Taken as a whole, the fact that this update did not confirm the earlier excess in melanoma suggests that the previous findings may have been due to chance.

We also found a non-significant, slight increase in malignant brain cancer among upstream workers. However, assessment by duration of employment and latency clearly showed no trend towards higher mortality in workers with longer duration and latencies. Several previous studies of petroleum workers have reported increased cancer of the brain and CNS, although these reports have been inconsistent, and the combined data indicate death rates as expected. ${ }^{46}$ The only other study of upstream workers ${ }^{40}$ found the highest mortality from brain cancer among unexposed workers. 
OTHER DISEASES

We found increased deaths due to aortic aneurysms among long duration, long latency marketing and distribution workers. There also was a non-significant increase in aortic aneurysms among refinery workers, which resulted in a significant increase of the broader category of diseases of arteries, arterioles, and capillaries. To date, there have been few studies of the relation between aortic aneurysms and occupational exposures, especially those relevant to the petroleum industry. However, one study of refinery $^{24}$ and distribution ${ }^{36}$ workers in the United Kingdom has reported strikingly similar results. Specifically, the broad category of diseases of arteries was increased in both refinery and distribution workers, with the increase being more pronounced in refinery workers. Further, in both instances, the increase was due to aortic aneurysms.

This evidence suggests a possible occupational influence for aortic aneurysms, but other factors detract from this hypothesis. These include $(a)$ the lack of a biologically plausible explanation for an occupationally related excess (be it chemical or physical exposures) and (b) the lack of reported increases in aortic aneurysms in other studies of petroleum workers. More importantly, an earlier Poisson regression analysis of mortality from aortic aneurysms relative to exposures to hydrocarbons among marketing and distribution workers in this cohort $^{7}$ showed a significant reduction in risk for higher frequencies of exposure. Non-occupational factors-such as increased blood pressure, ${ }^{41}{ }^{42}$ smoking, ${ }^{41}{ }^{42}$ atherosclerosis, ${ }^{43}$ high serum triglycerides ${ }^{44}$, or diagnostic practices ${ }^{45}$ - may have played a part in the increase, but we did not have data to evaluate these factors. ${ }^{45}$

We also found increased deaths from cancers related to the ovaries. This excess was focused among unexposed office workers. Moreover, analyses by duration of employment and latency showed the highest SMR in the group with shortest duration of employment; thus, the results are not internally consistent with an occupational effect.

Finally, amyotrophic lateral sclerosis was increased, although this was largely focused in unexposed office workers. A non-significant increase was also found among refinery workers. Analyses by duration of employment and latency for the total cohort indicated higher SMRs in employees with longer durations of employment and longer latencies, but no strong patterns were found; however, this analysis was based on small numbers (data not shown). Established risk factors for amyotrophic lateral sclerosis include age, sex (male), and genetic susceptibility. ${ }^{46}$ Some studies suggest a possible role of physical trauma, electric shock, vigorous physical exertion, working in various occupations, ${ }^{46}$ and occupational exposure to electric and magnetic fields, ${ }^{47} 48$ but these results are by no means definitive. One study reported a possible increased risk of amyotrophic lateral sclerosis associated with employment in the petroleum industry, but the authors cautioned that this was based on few subjects. ${ }^{49}$ To our knowledge, no other study of petroleum workers has reported excess deaths due to amyotrophic lateral sclerosis, although it is unclear how many studies have actually examined mortality for this specific cause of death. Future studies of employees from the petroleum industry should consider examining and reporting mortality for this disease.

\section{Summary and conclusions}

The results indicate that employees continue to experience a favourable overall health profile. Deaths due to kidney cancer, which have been increased in some studies of petroleum workers, were not increased. The most notable finding was significantly increased deaths due to mesothelioma among refinery and petrochemical workers, a finding that likely reflects past exposures to asbestos in this cohort. The only type of leukaemia found to be increased was acute non-lymphocytic leukaemia, but this increase was most pronounced in unexposed office workers. Multiple myeloma remained increased among marketing and distribution workers, but unlike the previous update, this disease showed no clear patterns by duration of employment or latency. Malignant melanoma among marketing and distribution workers returned to levels consistent with those expected in the update period. Although the number of deaths from malignant melanoma was small, the sixfold excess reported previously was not confirmed. Several other disease excesses were found, but these were not internally or externally consistent with an occupational effect. Thus, with the exception of mesothelioma in refinery workers, no clear increases in work related diseases were identified.

We thank Dr Martha Fair, Pierre Lalonde, and Dores Zuccarini of Statistics Canada for mortality follow up efforts, Eugene and Shirin Sotoudeh and Gail Wilson for data preparation. We are also grateful to Ian Drummond for his review of the manuscript.

1 Schnatter AR, Theriault G, Katz AM, et al. A retrospective mortality study within operating segments of a petroleum company. Am f Ind Med 1992;22:209-29.

2 Runion HE. Occupational exposures to potentially hazardous agents in the petroleum industry. Occup Med 1988;3:431-43

3 International Agency for Research on Cancer. Monograph on the evaluation of carcinogenic risks to humans: occupational exposures in petroleum refining, crude oil, and major petroleum fuels. IARC Monogr Eval Carcinog Risks Hum 1989;45:39-117.

4 Delzell E, Austin H, Cole P. Epidemiologic studies of the petroleum industry. Occup Med 1988;3:455-74.

5 Shallenberger LG, Acquavella JF, Donaleski D. An updated mortality study of workers in three major United States refineries and chemical plants. Br f Ind Med 1992;49:34554.

6 Wong O, Raabe GK. Critical review of cancer epidemiology in petroleum industry employees, with a quantitative metaanalysis by cancer site. Am F Ind Med 1989;15:283-310.

7 Schnatter AR, Katz AM, Nicolich MJ, et al. A retrospective mortality study among Canadian petroleum marketing and distribution workers. Environ Health Perspect 1993;101:8599.

8 Hanis NM, Stavraky KM, Fowler JL. Cancer mortality in oil refinery workers. f Occup Med 1979;21:167-74.

9 Gennaro V, Ceppi M, Boffetta P, et al. Pleural mesothelioma and asbestos among Italian oil refinery workers. Scand $\mathcal{F}$ Work Environ Health 1994;20:213-15.

10 Kaplan SD. Update of a mortality study of workers in petroKaplan SD. Update of a mortality study of worke

11 Reifenberg A. Amoco chemical studies the high rate of brain tumors among some staff. Wall Street fournal 1996:August 
12 Schnatter AR, Acquavella JF, Thompson FS, et al. An analysis of death ascertainment and follow-up through Statistics Canada's mortality data base system. Can F Public Health $1990 ; 81: 60-5$

13 Acquavella JF, Donaleski D, Hanis NM. An analysis of mortality follow-up through the national death index for a cohort of refinery and petrochemical workers. Am f Ind Med 1986;9:181-7.

14 Marsh GM, Ehland J, Park M, et al. OCMAP/PC: a user-oriented cohort mortality analysis program for the IBM PC. American Statistician 1986;40:308-9.

15 Haenszel W, Loveland D, Sirkin MG. Lung cancer mortality as related to residence and smoking histories. $\mathcal{F}$ Natl Cancer Inst 1962;28:947-1001.

16 Fox AJ, Collier PF. Low mortality rates in industrial cohort studies due to selection for work and survival in the industry. Br F Prev Soc Med 1976;30:225-30.

17 Monson RR. Observations on the healthy worker effect. $f$ Occup Med 1986;28:425-33.

18 Tsai SP, Waddell LC, Gilstrap EL, et al. Mortality among maintenance employees potentially exposed to asbestos in a refinery and petrochemical plant. Am f Ind Med 1996;29. 89-98.

19 Honda Y, Delzell E, Cole P. An updated study of mortality among workers at a petroleum manufacturing plant. $\mathscr{F}$ Occup Environ Med 1995;37:194-200.

20 Huebner WW, Schnatter AR, Nicolich MJ, et al. Mortality experience of a young petrochemical industry cohort: Environ Med 1997;39:970-82.

21 Price B. Analysis of current trends in United States mesothelioma incidence. Am f Epidemiol 1997;145:21118.

22 Peto J, Decarli A, La Vecchia C, et al. The European mesothelioma epidemic. Br f Cancer 1999;79:666-72.

23 Siemiatycki J, Dewar R, Nadon L, et al. Associations between several sites of cancer and twelve petroleumderived liquids. Results from a case-referent study in Monderived liquids. Results from a case-referent study in
treal. Scand 7 Work Environ Health 1987;13:486-92.

24 Rushton L. Further follow-up of mortality in a United Kingdom oil refinery cohort. Br F Ind Med 1993;50:549-

25 MacFarland HN, Ulrich CE, Holdsworth CE, et al. A chronic inhalation study with unleaded gasoline vapor. $\mathcal{F}$ Am Coll Toxicol 1984;1984:231-48.

26 Poole C, Dreyer NA, Satterfield MH, et al. Kidney cancer and hydrocarbon exposures among petroleum refinery workers. Environ Health Perspect 1993;101:53-62

27 Wen CP. Epidemiological studies of the role of gasoline (hydrocarbon) exposure in kidney cancer risk. Advances in Modern Environmental Toxicology 1984;7:245-58.

28 Wong O, Harris F, Smith TJ. Health effects of gasoline exposure. II. Mortality patterns of distribution workers in the United States. Environ Health Perspect 1993;(suppl 6):63-76.

29 Gamble JF, Pearlman ED, Nicolich MJ. A nested casecontrol study of kidney cancer among refinery/
petrochemical workers. Environ Health Perspect 1996;104: petrochemic
30 International Agency for Research on Cancer. Benzene. Some industrial chemicals and dyestuffs. Monographs on
the evaluation of the carcinogenic risk of chemicals to humans. IARC Monographs 1982;29:93-148.

31 Rinsky RA, Smith AB, Hornung R, et al. Benzene and leukemia: an epidemiologic risk assessment. $N$ Engl f Med 1987;316:1044-50.

32 Schnatter AR, Armstrong TW, Nicolich MJ, et al. Lymphohaematopoietic malignancies and quantitative estimates of exposure to benzene in Canadian petroleum distribution workers. Occup Environ Med 1996;53:773-81.

33 Siegel M. Smoking and leukemia: evaluation of a causal hypothesis. Am $\mathcal{F}$ Epidemiol 1993;138:1-9.

34 Davico L, Sacerdote C, Ciccone G, et al. Chromosome 8, occupational exposures, smoking, and acute nonlymphocytic leukemias: a population-based study. Cancer Epidemiol Biomarkers Prev 1998;7:1123-5.

35 Decoufle P, Blattner WA, Blair A. Mortality among chemical workers exposed to benzene and other agents. Environ Res 1983;30:16-25.

36 Rushton L. A 39-year follow-up of the UK oil refinery and distribution center studies: results for kidney cancer and distribution center studies: results for kidney can
leukemia. Environ Health Perspect 1993;101:77-84.

37 Wong O, Raabe GK. Multiple myeloma and benzene exposure in a multinational cohort of more than 250000 petroleum workers. Regul Toxicol Pharmacol 1997;26:188-99.

38 Wittmer JF. Selected reviews of the literature: melanomaupdate on etiology and control. F Occup Environ Med 1997; 39:823-4.

39 Melia J. Changing incidence and mortality from cutaneous malignant melanoma. BMF 1997;315:1106-7.

40 Divine BJ, Barron V. Texaco mortality study: III. A cohort study of producing and pipeline workers. Am f Ind Med 1987;11:189-202.

41 Doll R, Peto R. Mortality observations on male British doctors. BMF 1976;2:1525-36.

42 Strachan DP. Predictors of death from aortic aneurysm among middle-aged men: the Whitehall study. $\mathrm{Br} \mathcal{F}$ Surg 1991;78:401-4.

43 Reed D, Reed C, Stemmermann G, et al. Are aortic aneurysms caused by atherosclerosis? Circulation 1992;85: 205-11.

44 Watt HC, Law MR, Wald NJ, et al. Serum triglyceride: a possible risk factor for ruptured abdominal aortic aneurysms. Int $\mathcal{F}$ Epidemiol 1998;27:949-52.

45 Greenwald P, Friedlander BR, Lawrence CE, et al. Diagnostic sensitivity bias: an epidemiologic explanation for an apparent brain tumor excess. F Occup Med 1981;23:690-4.

46 Nelson LM. Epidemiology of ALS. Clin Neurosci 1995-96; 3:327-31

47 Savtiz DA, Checkoway H, Loomis DP. Magnetic field exposure and neurodegenerative disease mortality among electric utility workers. Epidemiology 1998;9:398-404.

48 Johansen $\mathrm{C}$, Olsen $\mathrm{JH}$. Mortality from amyotrophic lateral sclerosis, other chronic disorders, and electric shocks
among utility workers. Am $\mathcal{F}$ Epidemiol 1998;148:362-8.

49 Strickland D, Smith SA, Dolliff G, et al. Amyotrophic lateral sclerosis and occupational history. A pilot case-control study. Arch Neurol 1996;53:730-3.

\section{Correspondence and editorials}

Occupational and Environmental Medicine welcomes correspondence relating to any of the material appearing in the journal. Results from preliminary or small scale studies may also be published in the correspondence column if this seems appropriate. Letters should be not more than 500 words in length and contain a minimum of references. Tables and figures should be kept to an absolute minimum. Letters are accepted on the understanding that they be subject to editorial revision and shortening.

The journal also publishes editorials which are normally specially commissioned. The Editor welcomes suggestions regarding suitable topics; those wishing to submit an editorial, however, should do so only after discussion with the Editor. 